\title{
EVALUASI ATAS PEMENUHAN KEWAJIBAN PPh BADAN DAN MENENTUKAN ANGSURAN PPh PASAL 25 MELALUI EKUALISASI DAN REKONSILIASI PADA PT. EPS
}

\author{
Lutfi Fauziah \\ E-mail: lutfi.f1295@gmail.com \\ Jurusan Akuntansi, Institute Teknologi dan Bisnis Ahmad Dahlan Jakarta \\ J1. Ciputat Raya No.77, Cireundeu, Kec. Ciputat Tim., Kota Tangerang Selatan, Banten
}

\begin{abstract}
ABSTRAK
Penelitian ini bertujuan untuk mengetahui bagaimana Evaluasi Atas Pemenuhan Kewajiban PPh Badan dan Menentukan Angsuran PPh Pasal 25 Melalui Ekualisasi dan Rekonsiliasi Pada PT. EPS, sudah sesuai atau belum menurut UU No. 36 Tahun 2008. Jenis data yang digunakan adalah data primer yaitu data yang diambil oleh peneliti langsung dari seorang bagian accounting berupa informasi yang berkaitan dengan laporan keuangan dan pajak dan data sekunder yang diambil oleh peneliti adalah laporan keuangan komersial, laporan keuangan fiskal, SPT Tahunan. Teknik pengumpulan data yang dilakukan adalah dengan mengumpulkan dokumen-dokumen PT. EPS yang berhubungan langsung dengan laporan laba-rugi komersial tahun 2018. Metode analisis yang digunakan merupakan metode analisis kuantitatif. Berdasarkan hasil penelitian penulis menyimpulkan bahwa Evaluasi Atas Pemenuhan Kewajiban PPh Badan dan Menentukan Angsuran PPh Pasal 25 Melalui Ekualisasi dan Rekonsiliasi Pada PT. EPS tidak sesuai dengan UU No. 36 Tahun 2008 dan ditemukannya hasil akhir perhitungan yang Lebih Bayar sebesar (Rp. 134.649.156). Dengan adanya SPT Tahunan Badan yang lebih bayar maka perusahaan berhak melaporkan dan mengajukan permohonan atas kelebihan pajak tersebut atau disebut dengan restitusi dengan pengembalian atas kelebihan pembayaran. Namun DJP akan mereview kembali atau melakukan pemeriksaan kepada perusahaan tentang kebenaran atas lebih bayar tersebut.
\end{abstract}

Kata kunci : Evaluasi Pemenuhan Kewajiban PPh Badan, Angsuran PPh 25, Ekualisasi dan Rekonsiliasi

\section{ABSTRACT}

This study aims to find out how to Evaluate the Fulfillment of Corporate Income Tax Obligations and Determine Article 25 Income Tax Installments Through Equalization and Reconciliation at PT. EPS, whether or not according to Law No. 36 of 2008. Types of data used are primary data that is data taken by researchers directly from an accounting department in the form of information relating to financial and tax reports and secondary data taken by researchers are commercial financial statements, fiscal financial statements, annual notification letters . The technique of collecting data is by collecting PT. EPS which is directly related to the 2018 commercial income statement. The analytical method used is a quantitative analysis method. Based on the results of the study the authors concluded that the Evaluation of the Fulfillment of Corporate Income Tax Obligations and Determine Article 25 Income Tax Installments Through Equalization and Reconciliation at PT. EPS is not in accordance with Law No. 36 of 2008 and the discovery of the final results of the calculation that is more Pay for (Rp. 134,649,156). With the annual notification letter of the overpaid body, the company has the right to report and submit an application for the tax excess or referred to as restitution with a refund for the excess payment. However, DJP will review or examine the company about the truth of the overpayment.

Keywords: Evaluation of Fulfillment of Corporate Income Tax Obligations, Article 25 Income Tax Installments, Equalities and Reconciliation

\section{PENDAHULUAN}

Pajak merupakan sumber pendapatan utama Negara, khususnya Negara Indonesia. Pajak memiliki peran penting dalam hal meningkatnya anggaran pendapatan dan belanja Negara (APBN) setiap tahunnya. Dengan meningkatnya APBN tersebut menandakan bahwa 
kebutuhan ekonomi dan kebutuhan Negara semakin meningkat juga. Dilihat dari penerimaan pajak yang cukup besar, maka penanganannya haruslah optimal.

Berdasarkan UU KUP Nomor 28 Tahun 2007, pasal 1 ayat 1, pajak merupakan kontribusi wajib kepada Negara yang terutang oleh orang pribadi maupun badan yang bersifat memaksa untuk keperluan Negara bagi sebesar-besarnya kemakmuran rakyat. Untuk itu pembayaran pajak merupakan peran serta wajib pajak dalam kontribusinya kepada Negara untuk menjadikan Negara ini makmur dan sejahtera. Warga Negara yang baik sangatlah dibutuhkan dalam kesadarannya untuk melakukan kewajiban perpajakannya. Dengan membayar pajak warga Negara sudah melakukan perwujudan atas pengabdian sebagai warga Negara yang taat akan pajak. Dan dengan membayar pajak yang dilandasi oleh kesadaran warga Negara, Negara akan memberikan fasilitas yang baik sehingga masyarakat Indonesia dapat melakukan kegiatan usaha. Hal tersebut dapat dijadikan indikasi bahwa setiap warga Negara berkontribusi secara fiskal kepada kebijakan pemerintah dengan sukarela.

Pajak penghasilan Pasal 25 adalah pajak yang dikenakan baik untuk orang pribadi, perusahaan atau badan hukum lainnya atas penghasilan/pendapatan yang didapatkan. Pajak Penghasilan Pasal 25 atau biasa disingkat dengan PPh 25 merupakan angsuran pajak yang dibayarkan setiap bulan untuk tahun pajak yang bersangkutan. Sedangkan Pajak Penghasilan Pasal 29 atau PPh 29 merupakan kekurangan pajak yang terutang pada akhir tahun pajak.

Ekualisasi merupakan salah satu hal paling utama dalam melakukan rekonsiliasi fiskal dalam SPT Tahunan Badan. Ekualisasi pajak bertujuan untuk terhindarnya dari koreksi pajak. Selain itu juga sebagai antisipasi dalam hal persiapan wajib pajak jika dilakukan pemeriksaan oleh KPP. Dengan demikian, ekualisasi dapat digunakan untuk melacak dan memastikan apakah seluruh omzetnya sudah dipungut PPN. Kemudian dapat digunakan juga untuk memastikan apakah seluruh transaksi yang menjadi objek PPh Pasal 23 telah dipotong pajaknya. Serta apakah seluruh biaya gaji maupun upah tenaga kerja langsung sudah sama dengan jumlah biaya gaji pada laporan Laba/Rugi. Lalu kemudian diperhitungkan saat mengisi SPT PPh Wajib Pajak Badan sesuai dengan peraturan perpajakan yang berlaku.

Oleh karena itu diperlukan pemahaman yang baik terhadap pemenuhan kewajiban $\mathrm{PPh}$ Badan dalam penentuan angsuran PPh Pasal 25 melalui ekualisasi dan rekonsiliasi tersebut, yang membuat penulis tertarik untuk melakukan penelitian di PT. EPS 


\section{METODE PENELITIAN}

Penelitian ini menggunakan metode penelitian deskriptif kuantitatif yang merupakan penelitian ilmiah yang sistematis terhadap bagian-bagian fenomena serta kausalitas hubungan-hubungannya.

Menurut Sugiyono (2018) pengertian metode deskriptif adalah sebagai berikut:

"Metode deskriptif adalah metode menganalisis data yang digunakan dengan cara menggambarkan data atau mendeskripsikan data yang telah terkumpul sebagaimana adanya tanpa bermaksud membuat kesimpulan yang berlaku untuk umum atau generalisasi”

Menurut Sugiyono (2018) metode penelitian kuantitatif merupakan metode pengumpulan data menggunakan instrument penelitian, analisis data bersifat kuantitatif/statistik, dengan tujuan untuk menguji hipotesis yang telah ditetapkan yang berlandaskan pada filsafat positivisme, dan digunakan untuk meneliti populasi atau sampel tertentu,".

Berdasarkan keterangan diatas, dapat ditarik kesimpulan bahwa penelitian deskriptif kuantitatif adalah penelitian yang teknik pengumpulan datanya menggunakan instrument penelitian dengan analisis data bersifat statistik dengan tujuan untuk menguji hipotesis.

\section{HASIL DAN PEMBAHASAN}

Fokus penelitian ini adalah melakukan Evaluasi Atas Pemenuhan Kewajiban PPh Badan dan Menentukan Angsuran PPh 25 Melalui Ekualisasi dan Rekonsiliasi Pada PT. EPS.

\section{Laporan Keuangan Laba Rugi PT. EPS Tahun 2018}

PT. EPS merupakan perusahaan yang bergerak dibidang distribusi Panel Listrik. Data yang akan penulis olah adalah laporan keuangan komersial Pada PT. EPS. Berikut adalah laporan keuangan komersial PT. EPS yang manampilkan Laporan Laba/Rugi dalam periode laporan satu tahun yakni pada periode 01 Januari sampai dengan 31 Desember 2018.

Tabel 4.4

\section{Laporan Laba Rugi Komersial PT. EPS Tahun Berakhir 31 Desember 2018}

\begin{tabular}{|c|c|}
\hline \multicolumn{2}{|c|}{ PT. EPS } \\
\hline \multicolumn{2}{|c|}{ LAPORAN LABA - RUGI } \\
\hline \multicolumn{2}{|c|}{ PERIODE JANUARI - DESEMBER 2018 } \\
\hline \multicolumn{2}{|c|}{ (dalam satuan rupiah) } \\
\hline PENDAPATAN USAHA & Rp 31.269.818.847 \\
\hline Penjualan & - \\
\hline Potongan Penjualan & Rp 31.269.818.847 \\
\hline Jumlah Pendapatan Usaha &
\end{tabular}


Jurnal Ekonomi Pembangunan Vol. 6, No.1 (2020) 79-91

\begin{tabular}{|c|c|}
\hline HPP & \\
\hline Persedian Barang Dagang 01 Jan 2018 & $\begin{array}{ll}\mathrm{Rp} & 5.283 .148 .388\end{array}$ \\
\hline Pembelian & Rp $\quad 24.300 .460 .603$ \\
\hline Biaya Overhead & $\begin{array}{ll}\mathrm{Rp} & 1.215 .743 .613\end{array}$ \\
\hline Persedian Barang Dagang Akhir 31 Des 2018 & Rp $\quad 6.017 .556 .530$ \\
\hline Jumlah Harga Pokok Penjualan & Rp 24.781.796.074 \\
\hline LABA / ( RUGI ) KOTOR & Rp 6.488.022.773 \\
\hline \multicolumn{2}{|l|}{ BIAYA UMUM DAN ADMINISTRASI } \\
\hline Gaji, Tunjangan dan Bonus & Rp 2.743 .261 .848 \\
\hline Beban PPh-21 & $\mathrm{Rp} \quad 40.110 .650$ \\
\hline Beban Pengembanagan SDM & $\begin{array}{ll}\mathrm{Rp} & 11.000 .000\end{array}$ \\
\hline Beban Non Opr dan umum & $\mathrm{Rp} \quad 965.231 .298$ \\
\hline Beban Perjalanan Dinas & $\begin{array}{ll}\mathrm{Rp} & 1.722 .000\end{array}$ \\
\hline Beban Penjualan dan Pemasaran & Rp $\quad 261.678 .730$ \\
\hline Beban Telekomunikasi & $\mathrm{Rp} \quad 26.844 .679$ \\
\hline Beban Penerangan & $\mathrm{Rp} \quad 41.673 .927$ \\
\hline Beban Transportasi & $\begin{array}{ll}\mathrm{Rp} & 170.354 .500\end{array}$ \\
\hline Beban Perawatan Peralatan & $\mathrm{Rp} \quad 28.438 .050$ \\
\hline Beban Perawatan Kendaraan & $\mathrm{Rp} \quad 43.019 .111$ \\
\hline Beban Perawatan Bangunan & - \\
\hline Beban Jasa Kurir dan Benda Pos & $\mathrm{Rp} \quad 295.250$ \\
\hline Beban Perijinan & $\mathrm{Rp} \quad 750.000$ \\
\hline Beban Kesejahteraan Pegawai & Rp 236.679 .065 \\
\hline Beban Konsumsi & $\mathrm{Rp} \quad 4.080 .000$ \\
\hline Beban Penyususutan & Rp $\quad 414.085 .479$ \\
\hline Beban Perlengkapan & $\mathrm{Rp} \quad 54.580 .155$ \\
\hline Biaya Administrasi Bank & Rp 301.202 .802 \\
\hline Beban Bunga Bank Investasi & - \\
\hline Beban Bunga Modal Kerja & Rp $\quad 868.366 .464$ \\
\hline Kerugian Penjualan Aktiva & - \\
\hline Beban Bunga Kredit Lokal & $\mathrm{Rp} \quad 517.520 .325$ \\
\hline Beban Selisih Kurs & - \\
\hline Beban Bunga PB-BII & Rp $\quad 144.850 .611$ \\
\hline Beban Diskonto & $\mathrm{Rp} \quad 44.945 .927$ \\
\hline Beban Administrasi Pajak ( Sanksi Pajak ) & $\mathrm{Rp} \quad 17.036 .664$ \\
\hline Jumlah Biaya Administrasi dan Umum & Rp 6.937.727.535 \\
\hline \multicolumn{2}{|l|}{ Pendapatan dan Biaya dari Luar Usaha } \\
\hline Pendapatan lainya & - \\
\hline Bunga Jasa Giro & 755.456 \\
\hline Pajak Jasa Giro & 150.188 \\
\hline Total Pendapatan dan Biaya Lain-lain & $\mathrm{Rp} \quad 905.644$ \\
\hline Laba Rugi (EBIT) & Rp $\quad 448.799 .118$ \\
\hline
\end{tabular}




\begin{tabular}{|l|r|}
\hline Beban/ (Manfaat) Pajak Penghasilan & Rp 300.766 .720 \\
\hline Laba (Rugi) Setelah Pajak & Rp $\quad \mathbf{7 4 9 . 5 6 5 . 8 3 8 )}$ \\
\hline
\end{tabular}

\section{Sumber : Laporan Keuangan PT. EPS}

Berdasarkan data laporan laba rugi PT. EPS pendapatan yang diperoleh sejumlah Rp 31.269.818.847. Harga Pokok Penjualan sejumlah Rp 24.781.796.074 yang didapat dari hasil perhitungan Persediaan Barang dagang awal sejumlah Rp 5.283.148.388 ditambah dengan Pembelian sejumlah Rp 24.300.460.603, kemudian ditambah dengan Biaya Overhead sejumlah Rp 1.215.743.613 lalu kemudian dikurangi Persediaan Barang dagang akhir sejumlah Rp.6.017.556.530. Sehingga menghasilkan Laba Kotor perusahaan Rp. 6.488.022.773. Total biaya berjumlah Rp. 6.937.727.535 dan penghasilan serta beban di luar usaha berjumlah Rp.905.644 sehingga menghasilkan Laba Rugi Sebelum Pajak senilai Rp.448.799.118. Pajak Penghasilan perusahaan berjumlah Rp 300.766.720.

Dari laporan Laba/Rugi Komersial diatas menerangkan bahwa pada tahun 2018 PT. EPS menghasilkan Laba/Rugi sebelum pajak sebesar Rp. 448.799 .118 dan menghasilkan Rugi setelah pajak sebesar Rp (749.565.838).

Sehingga dapat disimpulkan bahwa pada tahun 2018 PT. EPS dalam laporan komersil mengalami kerugian sebesar $\operatorname{Rp}(749.565 .838)$.

\section{Rekonsiliasi Fiskal PT. EPS}

Tabel 4.5 Analisis Rekonsiliasi Fiskal PT. EPS

\begin{tabular}{|c|c|c|c|c|}
\hline & KOMERSIL & & KOREKSI & FISKAL \\
\hline PENDAPATAN USAHA & & POSITIF & NEGATIF & \\
\hline Penjualan & & & & \\
\hline Potongan Penjualan & Rp 31.269 .818 .847 & & Rp 75.477.300 & Rp 31.194 .341 .547 \\
\hline Jumlah Pendapatan Usaha & Rp 31.269.818.847 & & & \\
\hline HPP & & & & Rp 31.194.341.547 \\
\hline Persedian Barang Dagang 01 Jan & Rp 5.283 .148 .388 & & & \\
\hline Pembelian & Rp 24.300.460.603 & & & \\
\hline Biaya Overhead & Rp 1.215 .743 .613 & & & \\
\hline Persedian Barang Dagang Akhir 31 & Rp 6.017 .556 .530 & & & \\
\hline Des 2018 & Rp $\mathbf{2 4 . 7 8 1 . 7 9 6 . 0 7 4}$ & & & Rp 24.781.796.074 \\
\hline Jumlah Harga Pokok Penjualan & Rp $\mathbf{6 . 4 8 8 . 0 2 2 . 7 7 3}$ & & & Rp $\mathbf{6 . 4 1 2 . 5 4 5 . 4 7 3}$ \\
\hline LABA / RUGI ) KOTOR & & & & \\
\hline BIAYA UMUM DAN ADMINISTRASI & Rp 2.743.261.848 & & & \\
\hline Gaji, Tunjangan dan Bonus & & & & \\
\hline
\end{tabular}


Jurnal Ekonomi Pembangunan Vol. 6, No.1 (2020) 79-91

\begin{tabular}{|c|c|c|c|c|}
\hline Beban PPh-21 & 40.110 .650 & Rp 40.110 .650 & & - \\
\hline Beban Pengembanagan SDM & 11.000 .000 & & & 11.000 .000 \\
\hline Beban Non Opr dan umum & $\begin{array}{ll}\mathrm{Rp} & 965.231 .298\end{array}$ & Rp 206.341.992 & & $\begin{array}{ll}\mathrm{Rp} & 758.889 .306\end{array}$ \\
\hline Beban Perjalanan Dinas & $\begin{array}{ll}\mathrm{Rp} & 1.722 .000\end{array}$ & & & $\begin{array}{ll}\mathrm{Rp} & 1.722 .000\end{array}$ \\
\hline Beban Penjualan dan Pemasaran & $\begin{array}{ll}\mathrm{Rp} & 261.678 .730\end{array}$ & $\operatorname{Rp} 261.678 .730$ & & - \\
\hline Beban Telekomunikasi & 26.844 .679 & $\begin{array}{ll}\mathrm{Rp} & 1.750 .000\end{array}$ & & $\begin{array}{ll}\mathrm{Rp} & 25.094 .679\end{array}$ \\
\hline Beban Penerangan & 41.673 .927 & $\operatorname{Rp} 20.836 .964$ & & $\begin{array}{ll}R p & 20.836 .964 \\
\end{array}$ \\
\hline Beban Transportasi & $\begin{array}{ll}\mathrm{Rp} & 170.354 .500\end{array}$ & & & $\begin{array}{ll}\mathrm{Rp} & 170.354 .500\end{array}$ \\
\hline Beban Perawatan Peralatan & $\begin{array}{ll}\mathrm{Rp} & 28.438 .050\end{array}$ & & & $\begin{array}{ll}\mathrm{Rp} & 28.438 .050\end{array}$ \\
\hline Beban Perawatan Kendaraan & Rp $\quad 43.019 .111$ & Rp 21.509 .556 & & $\mathrm{Rp} \quad 21.509 .556$ \\
\hline Beban Perawatan Bangunan & - & & & \\
\hline Beban Jasa Kurir dan Benda Pos & 21.509 .556 & & & $\begin{array}{ll}\mathrm{Rp} & 21.509 .556 \\
\end{array}$ \\
\hline Beban Perijinan & $\begin{array}{ll}\mathrm{Rp} & 21.509 .556\end{array}$ & & & $\begin{array}{ll}\mathrm{Rp} & 21.509 .556 \\
\end{array}$ \\
\hline Beban Kesejahteraan Pegawai & Rp $\quad 236.679 .065$ & $\begin{array}{c}\mathrm{Rp} \\
236.679 .065\end{array}$ & & - \\
\hline Beban Konsumsi & $\mathrm{Rp} \quad 4.080 .000$ & $\begin{array}{c}\mathrm{Rp} \\
4.080 .000\end{array}$ & & - \\
\hline Beban Penyususutan & Rp 414.085 .479 & Rp 54.922.351 & & $\operatorname{Rp} 359.163 .128$ \\
\hline Beban Perlengkapan & $\begin{array}{ll}\mathrm{Rp} & 54.580 .155\end{array}$ & & & $\begin{array}{ll}\mathrm{Rp} & 54.580 .155\end{array}$ \\
\hline Biaya Administrasi Bank & $\begin{array}{ll}\mathrm{Rp} & 301.202 .802\end{array}$ & Rp 256.000.000 & & Rp 45.202 .802 \\
\hline Beban Bunga Bank Investasi & - & & & \\
\hline Beban Bunga Modal Kerja & $\begin{array}{ll}\mathrm{Rp} & 868.366 .464\end{array}$ & & & Rp 868.366 .464 \\
\hline Kerugian Penjualan Aktiva & - & & & \\
\hline Beban Bunga Kredit Lokal & $\mathrm{Rp} \quad 517.520 .325$ & $\begin{array}{c}\mathrm{Rp} \\
517.520 .325\end{array}$ & & - \\
\hline Beban Selisih Kurs & - & & & - \\
\hline Beban Bunga PB-BII & $\mathrm{Rp} \quad 144.850 .611$ & $\begin{array}{c}\mathrm{Rp} \\
144.850 .611\end{array}$ & & - \\
\hline Beban Diskonto & $\mathrm{Rp} \quad 44.945 .927$ & $\begin{array}{c}\mathrm{Rp} \\
44.945 .927\end{array}$ & & - \\
\hline Beban Administrasi Pajak ( Sanksi Pajak ) & Rp $\quad 17.036 .664$ & $\begin{array}{c}\mathrm{Rp} \\
17.036 .664\end{array}$ & & - \\
\hline Jumlah Biaya Administrasi dan Umum & Rp 6.937.727.535 & $\begin{array}{c}\text { Rp } \\
\text { 1.828.262.834 }\end{array}$ & Rp 75.477.300 & \\
\hline \multicolumn{5}{|l|}{$\begin{array}{l}\text { Pendapatan dan Biaya dari Luar } \\
\text { Usaha }\end{array}$} \\
\hline Pendapatan lainya & - & & & \\
\hline Bunga Jasa Giro & 755.456 & & $\begin{array}{c}\mathrm{Rp} \\
755.456\end{array}$ & \\
\hline Pajak Jasa Giro & 150.188 & & $\begin{array}{c}\mathrm{Rp} \\
150.188\end{array}$ & \\
\hline Total Pendapatan dan Biaya Lain-lain & $\mathrm{Rp} \quad 905.644$ & & & \\
\hline Laba Rugi (EBIT) & $\mathrm{Rp} \quad 448.799 .118$ & & & Rp 1.303.080.000 \\
\hline Beban/ (Manfaat) Pajak Penghasilan & $\begin{array}{ll}\mathrm{Rp} & 300.766 .720\end{array}$ & & & \\
\hline Laba (Rugi) Setelah Pajak & $\begin{array}{ll}\text { Rp } & (749.565 .838)\end{array}$ & & & \\
\hline
\end{tabular}




\section{Sumber : Laporan Keuangan PT. EPS}

Berdasarkan tabel diatas Analisis Rekonsiliasi fiskal diatas diketahui bahwa terdapat akunakun yang dapat diakui (deductible) maupun yang tidak dapat diakui (non-deductable) atas penghasilan kena Pajak Perusahaan. Diantaranya banyak akun yang tidak diperkenankan sebagai biaya yang bisa dikurangkan atas penhasilan. Maka akun-akun itu harus dikoreksi, baik positif maupun negative. Akun yang dikoreksi positif meliputi Beban PPh 21, Beban Non Opr dan umum, Beban Penjualan dan Pemasaran, Beban Telekomunikasi, Beban Penerangan, Beban Perawatan Kendaraan, Beban Kesejahteraan Pegawai, Beban Konsumsi, Beban Penyususutan, Biaya Administrasi Bank, Beban Bunga Kredit Lokal, Beban Bunga PB-BII, Beban Diskonto, dan Beban Administrasi Pajak ( Sanksi Pajak ).

Akun pada koreksi fiskal negatif yaitu Penjualan yang dikoreksi sebesar Rp 75.477.300 sehingga menghasilkan penghasilan fiskal sebesar Rp. 31.194.341.547 dan kemudian koreksi fiskal negatif pada pendapatan diluar usaha senilai Rp. 905.644.

\section{Perhitungan PPh Kurang (Lebih) Bayar PT. EPS}

Table 4.10

Analisis Perhitungan PPh Badan Kurang Bayar

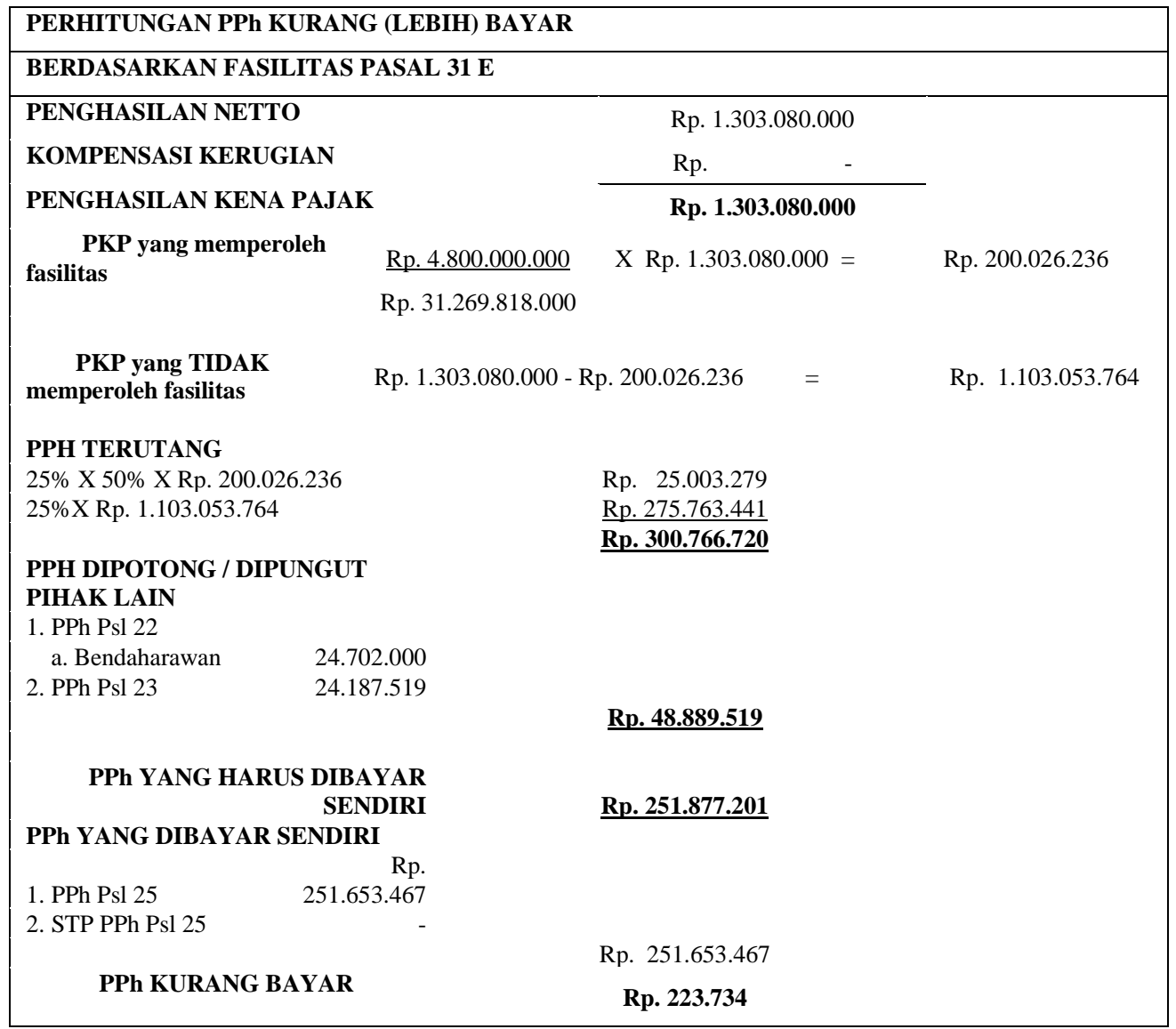


Jadi PPh Pasal 29 yang terutang senilai Rp. 300.766.720. Jumlah PPh terutang tersebut kemudian dikurangi oleh angsuran PPh Pasal 25, dan kredit pajak yakni, PPh Pasal 22 dan $\mathrm{PPh}$ Pasal 23. Sehingga menghasilkan jumlah PPh terutang yang harus dibayar menjadi Rp. 223.734 .

Adapun jurnal yang dilakukan oleh PT. Elco Power System yaitu:

- Jurnal pada saat mencatat PPh terutang

(D) Beban PPh Terutang $\quad$ Rp. 300.766.720

(K) Uang Muka PPh (Psl 22, 23 \& 25)

(K) Hutang PPh Pasal 29

Rp. 300.542 .986

Rp. 223.734

Setelah melakukan penghitungan PPh Pasal 29 yang terutang, maka langkah selanjutnya adalah menentukan berapa besaran PPh 25 terutang atas masa pajak tahun berikutnya.

Table 4.11

Analisis Perhitungan PPh Pasal 25 Tahun 2018

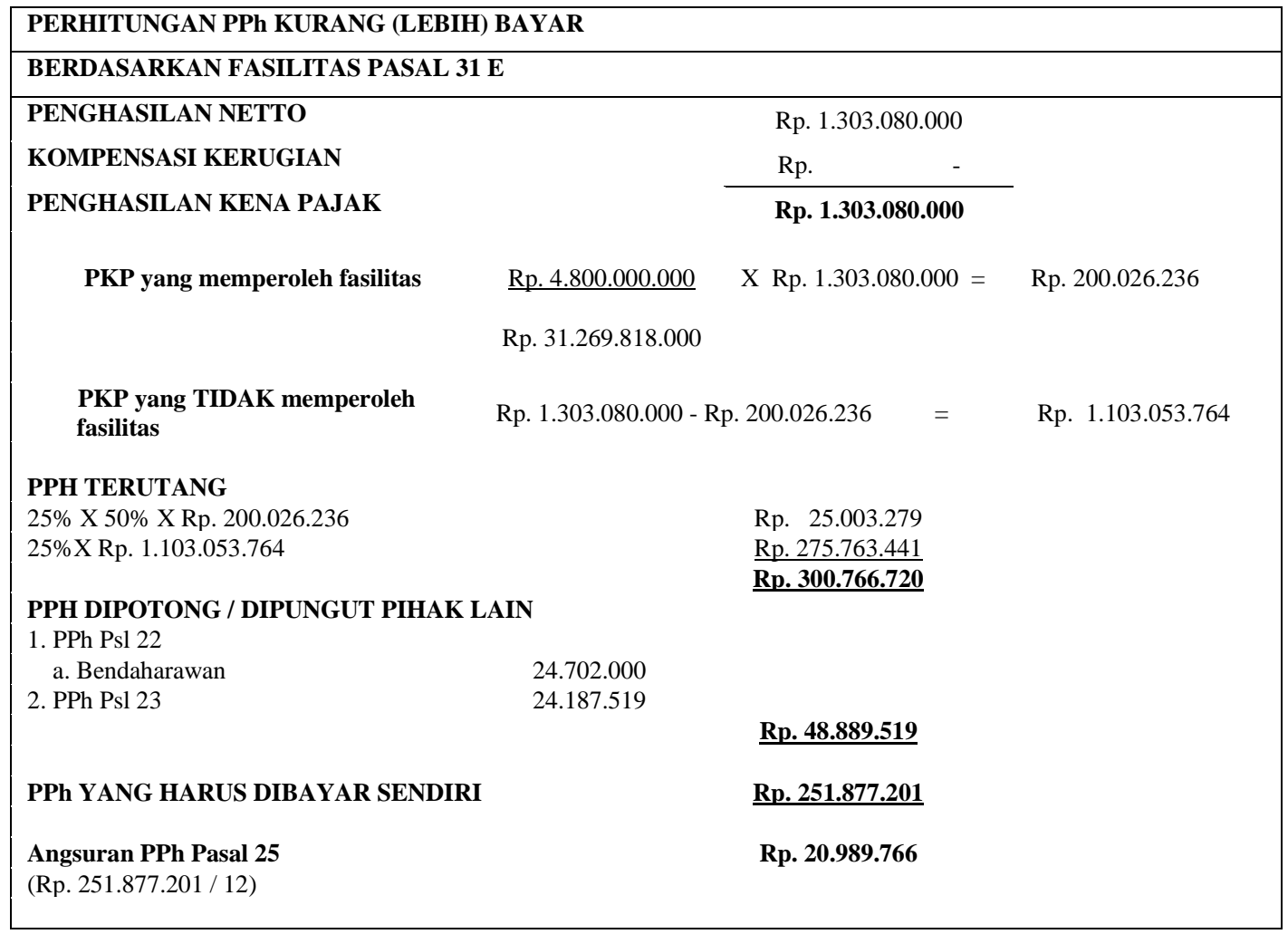




\section{PEMBAHASAN}

Bedasarkan laporan laba rugi perusahaan Penghasilan Kena Pajak yang terutang adalah sejumlah Rp. 1.303.080.000, jumlah tersebut merupakan penghasilan dibawah 4,8 M, maka akan mendapat fasilitas penurunan tarif sebesar 50\% sehingga tarif efektifnya adalah $12,5 \%$.

Adapun koreksi fiskal yang penulis lakukan terhadap hasil koreksi fiskal dari Perusahaan adalah seperti pada tabel koreksi di bawah ini.

\section{Analisis Rekonsiliasi Fiskal}

\begin{tabular}{|c|c|c|c|c|}
\hline & \multirow[t]{2}{*}{ KOMERSIL } & \multicolumn{2}{|c|}{ KOREKSI } & \multirow[t]{2}{*}{ FISKAL } \\
\hline & & POSITIF & NEGATIF & \\
\hline \multicolumn{5}{|l|}{ PENDAPATAN USAHA } \\
\hline Penjualan & $\mathrm{Rp} 31.269 .818 .847$ & & $\operatorname{Rp} 75.477 .300$ & Rp 31.194.341.547 \\
\hline Potongan Penjualan & - & & & \\
\hline Jumlah Pendapatan Usaha & Rp 31.269.818.847 & & & Rp 31.194.341.547 \\
\hline \multicolumn{5}{|l|}{ HPP } \\
\hline Persedian Barang Dagang 01 Jan 2018 & $\begin{array}{ll}\mathrm{Rp} & 5.283 .148 .388\end{array}$ & & & \\
\hline Pembelian & Rp 24.300 .460 .603 & & & \\
\hline Biaya Overhead & $\begin{array}{ll}\mathrm{Rp} & 1.215 .743 .613\end{array}$ & & & \\
\hline $\begin{array}{l}\text { Persedian Barang Dagang Akhir } 31 \\
\text { Des } 2018\end{array}$ & Rp $\quad 6.017 .556 .530$ & & & \\
\hline Jumlah Harga Pokok Penjualan & Rp 24.781.796.074 & & & Rp 24.781.796.074 \\
\hline LABA / ( RUGI ) KOTOR & Rp 6.488.022.773 & & & Rp 6.412.545.473 \\
\hline \multicolumn{5}{|l|}{ BIAYA UMUM DAN ADMINISTRASI } \\
\hline Gaji, Tunjangan dan Bonus & $\begin{array}{ll}\mathrm{Rp} & 2.743 .261 .848\end{array}$ & & & Rp $\quad 2.743 .261 .848$ \\
\hline Beban PPh-21 & $\mathrm{Rp} \quad 40.110 .650$ & $\mathrm{Rp} \quad 40.110 .650$ & & - \\
\hline Beban Pengembanagan SDM & Rp $\quad 11.000 .000$ & & & $\begin{array}{ll}\mathrm{Rp} & 11.000 .000\end{array}$ \\
\hline Beban Non Opr dan umum & Rp $\quad 965.231 .298$ & Rp 206.341.992 & & Rp 758.889 .306 \\
\hline Beban Perjalanan Dinas & $\begin{array}{ll}\mathrm{Rp} & 1.722 .000\end{array}$ & & & $\mathrm{Rp} \quad 1.722 .000$ \\
\hline Beban Penjualan dan Pemasaran & Rp 261.678 .730 & Rp 261.678.730 & & - \\
\hline Beban Telekomunikasi & Rp $\quad 26.844 .679$ & $\mathrm{Rp} \quad 13.422 .339$ & & $\begin{array}{ll}\mathrm{Rp} & 13.422 .339\end{array}$ \\
\hline Beban Penerangan & $\begin{array}{ll}\mathrm{Rp} & 41.673 .927\end{array}$ & & & Rp $\quad 41.673 .927$ \\
\hline Beban Transportasi & $\begin{array}{ll}\mathrm{Rp} & 170.354 .500\end{array}$ & & & $\begin{array}{ll}\mathrm{Rp} & 170.354 .500\end{array}$ \\
\hline Beban Perawatan Peralatan & $\mathrm{Rp} \quad 28.438 .050$ & & & Rp $\quad 28.438 .050$ \\
\hline Beban Perawatan Kendaraan & Rp $\quad 43.019 .111$ & $\operatorname{Rp} 21.509 .556$ & & Rp $\quad 21.509 .556$ \\
\hline Beban Perawatan Bangunan & - & & & \\
\hline Beban Jasa Kurir dan Benda Pos & Rp 295.250 & & & 295.250 \\
\hline Beban Perijinan & Rp $\quad 750.000$ & & & $\begin{array}{ll}\mathrm{Rp} & 750.000\end{array}$ \\
\hline Beban Kesejahteraan Pegawai & Rp $\quad 236.679 .065$ & Rp $\quad 236.679 .065$ & & - \\
\hline Beban Konsumsi & Rp $\quad 4.080 .000$ & $\mathrm{Rp} \quad 4.080 .000$ & & - \\
\hline Beban Penyususutan & Rp $\quad 414.085 .479$ & Rp 54.922.351 & & $\operatorname{Rp} 359.163 .128$ \\
\hline Beban Perlengkapan & $\mathrm{Rp} \quad 54.580 .155$ & & & $\mathrm{Rp} \quad 54.580 .155$ \\
\hline Biaya Administrasi Bank & Rp $\quad 301.202 .802$ & & & $\mathrm{Rp} \quad 301.202 .802$ \\
\hline Beban Bunga Bank Investasi & - & & & \\
\hline Beban Bunga Modal Kerja & $\mathrm{Rp} \quad 868.366 .464$ & & & Rp 868.366 .464 \\
\hline Kerugian Penjualan Aktiva & - & & & \\
\hline Beban Bunga Kredit Lokal & $\mathrm{Rp} \quad 517.520 .325$ & $\mathrm{Rp} \quad 388.140 .244$ & & $\begin{array}{ll}\mathrm{Rp} & 129.380 .081\end{array}$ \\
\hline Beban Selisih Kurs & - & & & - \\
\hline
\end{tabular}


Jurnal Ekonomi Pembangunan Vol. 6, No.1 (2020) 79-91

\begin{tabular}{|c|c|c|c|c|}
\hline Beban Bunga PB-BII & $\begin{array}{ll}\mathrm{Rp} & 144.850 .611\end{array}$ & & & Rp 144.850 .611 \\
\hline Beban Diskonto & $\mathrm{Rp} \quad 44.945 .927$ & & & Rp $\quad 44.945 .927$ \\
\hline Beban Administrasi Pajak ( Sanksi Pajak ) & Rp $\quad 17.036 .664$ & Rp $\quad 17.036 .664$ & & - \\
\hline Jumlah Biaya Administrasi dan Umum & Rp 6.937.727.535 & Rp 1.243.921.591 & Rp 75.477.300 & Rp. 5.693.805.944 \\
\hline \multicolumn{5}{|l|}{ Pendapatan dan Biaya dari Luar Usaha } \\
\hline Pendapatan lainya & - & & & \\
\hline Bunga Jasa Giro & 755.456 & & $\mathrm{Rp} \quad 755.456$ & \\
\hline Pajak Jasa Giro & 150.188 & & $\begin{array}{ll}\mathrm{Rp} & 150.188\end{array}$ & \\
\hline Total Pendapatan dan Biaya Lain-lain & $\mathrm{Rp} \quad 905.644$ & & & - \\
\hline Laba Rugi (EBIT) & Rp $\quad(448.799 .118)$ & & & Rp 718.739.529 \\
\hline Beban/ (Manfaat) Pajak Penghasilan & Rp 300.766 .720 & & & \\
\hline Laba (Rugi) Setelah Pajak & Rp $\quad(749.565 .838)$ & & & \\
\hline
\end{tabular}

Table 4.16

\section{Perhitungan PPh Badan Kurang/Lebih Bayar}

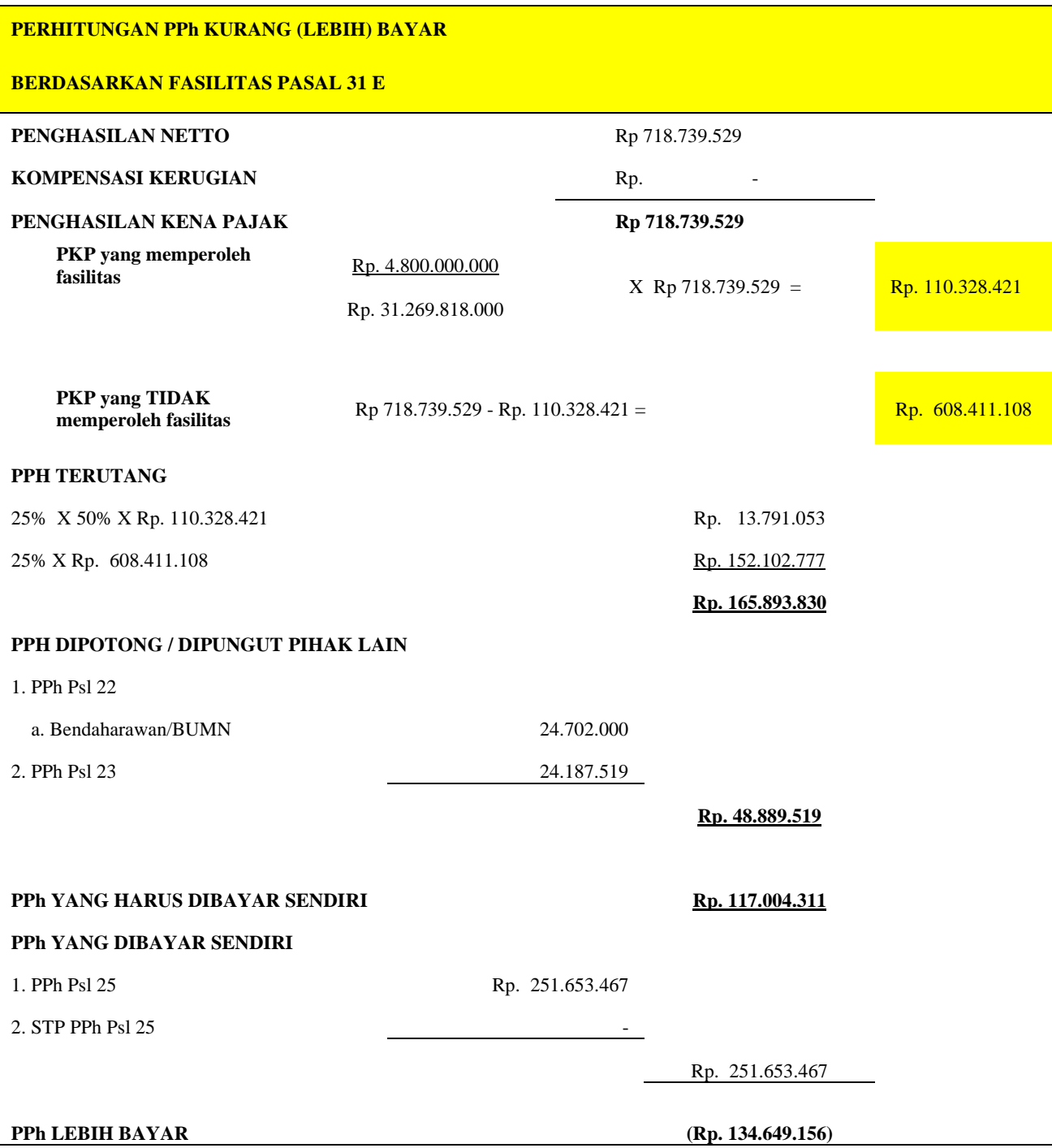


Dari hasil perhitungan diatas bahwa jumlah PPh yang seharusnya adalah lebih bayar senilai (Rp.134.649.156) dan bukanlah pph terutang kurang bayar senilai Rp. 223.734. Atas perhitungan perusahaan tersebut perlu melakukan SPT Pembetulan sesuai peraturan perundang-udangan yang berlaku.

\section{KESIMPULAN}

Berdasarkan hasil penelitian yang penulis lakukan mengenai "Evaluasi Atas Pemenuhan Kewajiban PPh Badan dan Menentukan Angsuran PPh 25 Melalui Ekualisasi dan Rekonsiliasi Pada PT. EPS" tahun 2018, maka penulis mengambil kesimpulan sebagai berikut:

1. Evaluasi Atas Pemenuhan Kewajiban PPh Badan dan Menentukan Angsuran PPh 25 Melalui Ekualisasi dan Rekonsiliasi Pada PT. EPS tidak sesuai dengan Undangundang No. 36 tahun 2008.

2. Mekanisme penyetoran PPh Pasal 25 PT. EPS belum sesuai dengan peraturan Undang-undang akan hal batas akhir penyetoran pajak.

3. Mekanisme kesesuaian proses pemenuhan kewajiban PPh Badan yang dilakukan PT. EPS tidak sesuai dengan Undang-undang No. 36 Tahun 2008 dan ditemukannya hasil akhir perhitungan yang Lebih Bayar sebesar (Rp. 134.649.156). Dengan adanya SPT Tahunan Badan yang lebih bayar maka perusahaan berhak melaporkan dan mengajukan permohonan atas kelebihan pajak tersebut atau disebut dengan restitusi dengan pengembalian atas kelebihan pembayaran. Namun DJP akan mereview kembali atau melakukan pemeriksaan kepada perusahaan tentang kebenaran atas lebih bayar tersebut.

\section{SARAN}

Untuk mencegah dikenakannya sanksi perpajakan, maka sebaiknya PT. EPS melakukan pemungutan dan menyetorkan pungutan tersebut tepat waktu bersamaan dengan pembayaran atas penyerahan barang dan paling lama tanggal 10 (sepuluh) bulan berikutnya setelah Masa pajak berakhir sesuai dengan ketentuan, saat pembuatan Surat Pemberitahuan Masa PPN sebaiknya PT. EPS menyampaikan laporan ke KPP tepat waktu dari tanggal 20 (dua puluh) dan paling lambat tanggal terakhir pada bulan setelah Masa Pajak berakhir dan sebaiknya perusahaan tersebut dapat memahami mengenai tata cara perhitungan, penyetoran, pelaporan 
dan ketentuan dalam UU Perpajakan baik itu UU PPN, UU PPh, dan juga UU KUP sehingga memiliki kewaspadaan dalam pelaporan pajak kepada pemerintah.

Dalam hal SPT yang lebih bayar akan adanya pemeriksaan yang dilakukan DJP kepada perusahaan, maka perlunya kesiapan data yang lengkap untuk mendukung pemeriksaan dokumen yang dibutuhkan pajak. Perusahaan juga bisa menghindari adanya lebih bayar agar tidak terjadi pemeriksaan yang membutuhkan waktu lama sehingga mengganggu aktivitas produksi para staff perusahaan maka perusahaan bisa juga mengajukan permohonan pengurangan pembayaran $\mathrm{PPh}$ Pasal 25 pada tahun berjalan, hal ini sesuai dengan Pasal 7 ayat (1) Keputusan Dirjen Pajak Nomor Kep.537/PJ./2002 tentang penghitungan besarnya Angsuran pajak dalam tahun pajak dalam hal-hal tertentu mengenai pengurangan angsuran PPh pasal 25 yang menyatakan bahwa apabila sesudah 3 (tiga) bulan atau lebih berjalanya suatu tahun pajak, wajib pajak dapat menunjukan bahwa pajak penghasilan yang akan terutang untuk tahun pajak tersebut kurang dari $75 \%$ dari pajak penghasilan yang terutang yang menjadi dasar penghitungan besarnya pajak penghasilan pasal 25, wajib pajak dapat mengajukan permohonan pengurangan besarnya pajak penghasilan pasal 25 secara tertulis kepada kepala kantor pelayanan Pajak tempat wajib pajak terdaftar.

\section{DAFTAR PUSTAKA}

Diana, Sari. 2014. Perpajakan: Konsep, Teori. dan Aplikasi Pajak Penghasilan. Jakarta: Mitra Wacana Media.

Liberti, Pandiangan. 2014. Administrasi Perpajakan. Jakarta: Penerbit Erlangga.

Mardiasmo. 2018. Perpajakan Edisi Terbaru. Yogyakarta: Andi

Pangestu D D A L. 2017. Perpajakan Brevet A\&B. Yogyakarta. Center For Academic Publishing Service

Siti, Resmi. 2016. Praktikum Perpajakan. Jakarta : Salemba Empat. Edisi 9. 2019. Perpajakan: Teori dan Kasus. Jakarta : Salemba Empat. Edisi 11.

YB. Sigit, Hutomo. 2018. Terampil Pajak Penghasilan. Yogyakarta : Andi. Edisi 1.

Waluyo. 2017. Perpajakan Indonesia Edisi 12 Buku 1. Jakarta: Salemba Empat.

A.A Istri, Shintia Dewi dan Putu Ery Setiawan. 2015. Penerapan Tax Review atas Pajak Penghasilan Badan Sebagai Dasar Evaluasi Kewajiban Perpajakan. ISSN 2302 - 8556 E - Jurnal Akuntansi Universitas Udayana Vol.13. 
I, Kadek Agus Setiawan dan Putu Ery Setiawan. 2018. Penerapan Tax Review Sebagai Dasar Evaluasi Atas Pemenuhan Kewajiban Perpajakan PPh Badan dan PPN. ISSN 2302 8556 E - Jurnal Akuntansi Universitas Udayana Vol.22.1.

Ni, Ketut Sukasih. 2016. Pemeriksaan Tingkat Keseimbangan (Equalisasi) PPh Pasal 21 dan Pengakuan Biaya Gaji (PPh 29) Pada Laporan Laba Rugi Pada Rumah Sakit Manuaba Di Denpasar. Jurnal Bisnis Dan Kewirausahaan Vol.12. No.3. 